\title{
If These Walls Could Speak: A Visual Ethnography of Graffiti at Boggo Road Gaol
}

\author{
Belinda Costanzo, Melissa Bull and Catrin Smith \\ m.bull@griffith.edu.au
}

When analysed in context, prison graffiti can provide valuable insight into the lived experiences of incarcerated individuals. This study uses Brisbane's Boggo Road Gaol as a case study site to evaluate the importance of historical, social and political context in the interpretation of prison graffiti. Visual ethnographic methodology was employed to allow the triangulation of various contextualising resources: newspaper articles, government reports, biographies and institutional records, and the graffiti. We discuss the theme of resistance as an example to demonstrate the value of the contextual analysis of images. By locating the graffiti within the historical, social and political context that it was produced, the significance of the graffiti is identified, and the ambiguity associated with the interpretation of images potentially is reduced. A contextualised analysis of prison graffiti provides a narrative of prison life, allowing the independent expression of prisoners to be 'heard'.

The end of the 1980s is often cited as a turning point for the criminal justice system in Queensland. Most often, this is associated with the 1989 Commission of Inquiry into Possible Illegal Activities and Associated Police Misconduct — or the Fitzgerald Inquiry, as it is widely known - which drew public attention to misconduct and corruption among Queensland police officers and political figures. While the Fitzgerald Inquiry largely focused on the operations and processes of the Queensland Police Force (as it was then known), other official inquiries were concerned with the practices of corrective services in Queensland - the Commission of Review into Corrective Services in Queensland (Kennedy 1988a, 1988b) and the Royal Commission into Aboriginal Deaths in Custody (hereafter RCIADIC) (Johnston 1991).

In February 1988, the then government commissioned a prominent businessman, Jim Kennedy, to review corrective services in Queensland. Kennedy's report signalled the need for significant change in the prison system. He identified three over-arching problems: a critical lack of resources; an inadequate organisational structure; and a lack of equity and efficiency in the way the corrections system treats offenders. The report listed the symptoms of the problems as poor morale among prison officers and a fragmented correctional service; a poor public image; excessive crowding of inmates into inadequate facilities and grossly outdated and inhuman facilities in parts of the two main prisons (including Boggo Road Gaol); 
inadequate access to and processes of justice inside prisons; the imprisonment of some offenders who perhaps might have been better directed to community-based sentences; problems with segregation of classes of offenders; and inequity, inefficiency and a lack of due process in the parole system (Public Sector Management Commission 1993). It ultimately led to the closure of Boggo Road Goal, describing it as 'a relic of the last century and hopelessly inadequate to provide corrective services today' (Kennedy 1988b: 2).

The Kennedy Review provided an official account of prisoner unrest at the facility; however, there remains little information on prisoners' perspectives of Boggo Road Gaol. One of the many criticisms of research on imprisonment and prisoners is that it is almost always mediated through the prism of official data (like prison statistics or government reports), research instruments like surveys and questionnaires, or the researcher's own background and interest. As a result, it is difficult to hear the voice of prisoners and develop an understanding of the experience of incarceration from their point of view. One way of accessing this very personal experience is through ethnographic work that analyses the stories prisoners tell. This article explores the possibility of using visual ethnography to understand the experience through an analysis of prisoner graffiti done on cell walls in Boggo Road before its closure in 1989. It offers a methodologically focused analysis that asks whether this approach can help us to understand the fragments of life inscribed on the prison walls at a particular point in Queensland's history.

Graffiti is 'any unauthorised inscription, word, figure, painting or other defacement that is written, marked, etched, scratched, sprayed, drawn, painted or engraved on or otherwise affixed to any surface of public or private property' (Willet 1996: 1). Research has been conducted on graffiti in a range of settings, including toilets (Abel and Buckley 1977; Sechrest and Flores 1969; Wales and Brewer 1976), schools (Stocker et al. 1972), urban and rural spaces (Alderman and Ward 2008; Rodriguez and Clair 1999) and, to a limited degree, correctional institutions (Johnson 2009; Wilson 2008a; Yogan and Johnson 2006). Abel and Buckley (1977: 3 ) claim that graffiti is 'a form of communication that is both personal and free of everyday social restraints that normally prevent people from giving uninhibited reign to their thoughts'. From this perspective, graffiti is an interesting source of data. It can be viewed as an artefact of everyday life that provides insight into the independent expression of the individuals who created the images.

An extensive review of graffiti studies reveals that a vast amount of research (e.g. Abel and Buckley 1977; Otta et al. 1996; Stocker et al. 1972) focuses on the manifest content - 'those elements that are physically present and countable' (Berg 2009: 343) - of the images under study. Often the graffiti has been quantified to allow comparative analysis based on presumed characteristics of the artists of the images, such as gender (Otta et al. 1996; Wales and Brewer 1976; Yogan and Johnson 2006) and ethnicity (Olowu 1983; Sechrest and Flores 1969). Generally, studies focusing on the manifest content of graffiti are descriptive in nature rather than interpretative. Other studies (Alderman and Ward 2008; Hagen et al. 1999; Hanauer 2004; Klingman and Shalev 2001) have focused on the graffiti that has emerged in response to specific events, such as natural disasters. Event-related graffiti studies tend to develop a functional analysis of the social purpose of the graffiti as it is situated in relation to the trigger event. Any consideration of context 
is limited to the specific event rather than the broader historical, social and political context.

Relatively few contemporary studies have considered the specific historical, social and political conditions that contribute to the production and content of graffiti. In relation to graffiti in correctional institutions, Klofas and Cutshall (1985) and Wilson (2008a, 2008b, 2008c, 2008d) have claimed to conduct contextual analyses of the images. Their analyses, however, did not clearly demonstrate how context was operationalised, or how it contributed to their conclusions. Rather than interpreting what the graffiti reflected at a broader level, Klofas and Cutshall (1985) focused mainly on how the content of the graffiti differed according to its location in the custodial facility. In contrast, Wilson $(2008 \mathrm{~b}, 2008 \mathrm{c})$ provides a rich interpretation of isolated items of graffiti, although it is not clear how the contextual data employed in her study contributes to the analysis.

We argue that much more attention needs to be paid to the historical, social and political context surrounding the creation of the graffiti, and this is made possible through visual ethnography. This article reports on a case study of graffiti at Brisbane's Boggo Road Gaol. It begins by providing a brief description of Boggo Road Gaol, then identifies the methods used in the current study to allow a systematic appreciation of the context surrounding the production of the images under study. Finally, it reports the findings of a visual ethnographic analysis of prison graffiti, focusing on the theme of resistance, which was one of three themes identified in a broader study of Boggo Road prison graffiti. Two other themes - identity and coping - were also represented. Here we report only on resistance, due to the limits of space and because it was the predominant theme evident in the larger body of work. By triangulating the content of graffiti images associated with this theme with other relevant cultural products - newspapers, government reports, biographies and other archival documents - we demonstrate what context can 'add' to the interpretation of images. We conclude by discussing how broadening the scope of analysis through the use of the visual ethnographic method to include historical, social and political context enhances the quality of graffiti as a source of data, and increases our understanding of prisoners' experience of Boggo Road Gaol.

\section{Boggo Road Gaol, Brisbane, Australia}

Boggo Road Gaol, officially titled H.M. Prison Brisbane when it opened, has played a significant role in Queensland's Corrective Services history. Throughout its operational years, the Boggo Road Prison Complex consisted of three main prisons: No. 1 Division, No. 2 Division, and a Women's Prison. No. 1 Division was the first prison to be built on the site. It began operation in 1883 and initially housed short-term prisoners and those awaiting execution (Dawson 2005). From the late 1960s until the mid-1970s, No. 1 Division gradually was demolished and reconstructed. The 'new' No. 1 Division remained in operation until 1992 (Boggo Road Gaol Historical Society: BRGHS 2013). The second prison (No. 2 Division) opened as a women's prison in 1903; however, in response to the low numbers of women prisoners that were ultimately housed there, it was transformed into a maximum security prison for men in 1921 (Dawson and Wood 2005). No. 2 Division was decommissioned in 1989. The third main prison on the site was a Women's 


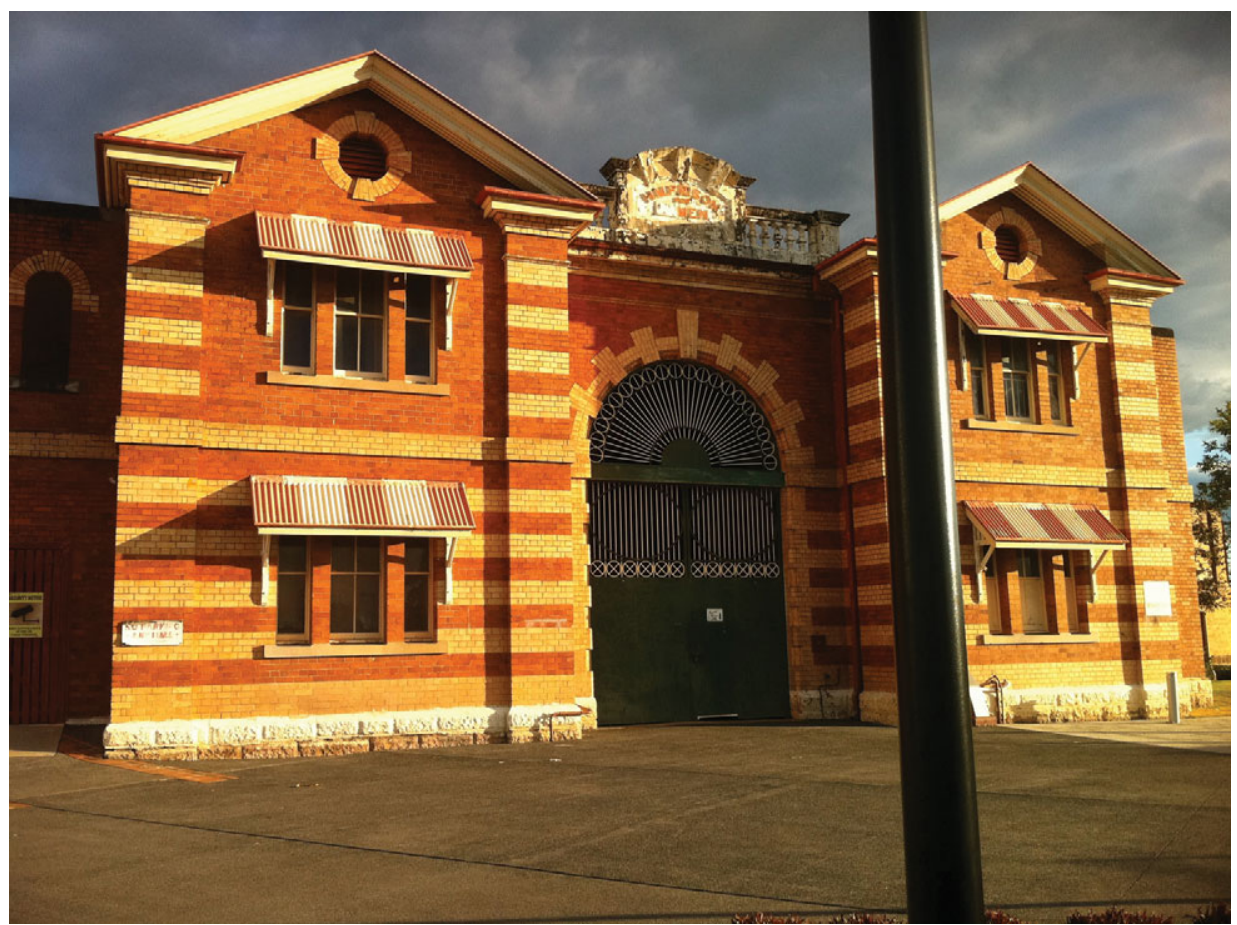

Figure 1 (Colour online) Entrance to No. 2 Division. Source: Private collection.

Division that operated from 1951 until 1998 (The State of Queensland, Department of Community Safety 2013) and was demolished during the late 2000s (BRGHS 2013). In addition to the three main prisons, a further compound on the site operated as No. 3 Division between the 1950s and 1970s to contain 'very short-term prisoners' (Dawson 2007: 16).

During the 1970s and 1980s, the Boggo Road Complex, in particular No. 1 and No. 2 Divisions, was the site of turmoil and unrest among both staff and prisoners (Dawson and Wood 2005). Similar to other Australian men's prisons commissioned in the nineteenth and early twentieth centuries (see Bull 2010; Findlay 1982; Victorian Office of Corrections 1990; Zdenkowski and Brown 1982), numerous strikes, protests and riots occurred at the site. This prompted the setting up of the Commission of Review into Corrective Services in Queensland, which began in 1988, and ultimately led to the closure of the prisons (No. 2 Division in 1989, and No. 1 Division in 1992).

Today, No. 2 Division is the only former prison that remains in its entirety on the Boggo Road Complex (see Figure 1). It contains three cell blocks; D, E and F. Each cell block consists of three levels and contains 42 cells. During the prison's operational years, each cell contained a bed (or, during some periods, a hammock), a small storage unit and, due to the absence of running water in the cells, a bucket used as a toilet (Dawson and Wood 2005). There were no cooling or heating devices in the cells, and the windows only contained bars, providing no reprieve from the elements of the weather. Until 2005, public tours and sleepovers were held at No. 
2 Division. Today, only one cell block (F) is open for public tours. Access to the remainder of the complex is restricted due to redevelopment.

\section{Methodology}

This article draws from a larger research project that consisted of a visual ethnographic investigation of the value of analysing prison graffiti in context. A central concern of visual ethnography is that images do not simply exist; rather, both the creation and interpretation of images are socially embedded (Pink 2007). As a result, while placing images at the centre of social inquiry, visual ethnography draws on a variety of data sources to gain an understanding of the context in which they were produced (Pink 2007). The current study examined graffiti inscribed on the walls of No. 2 Division of Boggo Road Gaol in the years preceding its closure in 1989. This is a cumulative set of images that have endured as the walls have deteriorated. A wide range of resources, including archives of newspaper articles, official reports, institutional records and autobiographies, provided data describing the historical, social and political context surrounding the production of the images.

In July 2011, a convenience sample of graffiti was photographed from nine cells in D block and three cells in F block of No. 2 Division. Thirty-two photographs were taken of the cell walls, and a total of 118 items of graffiti were recorded. Deterioration of both the graffiti and the cell walls made it necessary to adjust the colour and exposure of photographs. After cleaning the photographs with Windows Photo Gallery, the final data set contained 108 items of graffiti.

We also conducted an archival search of articles in the Courier-Mail that referred to Boggo Road Gaol between May 1987 and April 1988, focusing on the time period immediately preceding the Commission of Review into Corrective Services in Queensland (which ultimately led to the closure of No. 2 Division). Newspaper articles provide social context and allow an unobtrusive measure of public issues and debate (Altheide 1996). The date range selected allowed issues that attracted the attention of the media in Boggo Road Gaol's final years to be assessed. News and Letters to the Editor sections of the newspaper were searched for articles mentioning Boggo Road Gaol (or its alternative titles, including Boggo Road Jail, Brisbane Jail, Brisbane Prison or H. M. Prison Brisbane) and including both No. 1 and No. 2 Divisions and the Women's Prison. A total of 119 articles were identified.

The official reports of three major investigations relevant to the Queensland Criminal Justice System in the 1980 s provided empirical detail describing the political context surrounding the graffiti created at Boggo Road Gaol. They included both the interim and full report of the Commission of Review into Corrective Services in Queensland (Kennedy Review) (Kennedy 1988a, 1988b), which provided information regarding the administration and operation of corrective services in Queensland; the report of the Commission of Inquiry into Possible Illegal Activities and Associated Police Misconduct (Fitzgerald Inquiry) (Fitzgerald 1989), which reported on official misconduct and corruption within Queensland's Police Service and misconduct among Queensland political figures; and the report of the RCIADIC (Johnston 1991), which included The Regional Report of Inquiry in Queensland (Wyvill 1990), describing the circumstances surrounding the deaths of Aboriginal and Torres Strait Islander people in custody, the broader inequalities 
they faced within the criminal justice system and the history of Indigenous and non-Indigenous relations.

Documents held at the Queensland State Archives were reviewed to gain an understanding of the institutional historical context in which the graffiti at Boggo Road Gaol was created. These included the Prison rules and orders book, 1957-61 (QSA Item ID 271617), the Superintendent's punishment book, 1959-71 (QSA Item ID 271619) and chief prison officers' journals 1979-80 (QSA Item ID 304101), 1980-81 (QSA Item ID 304103) and 1982-83 (QSA Item ID 304104; 304105). Access to the Prison rules and orders book is available to the public; however, access to all of the other documents was held under the authority of the Department of Community Safety. Permission to access the restricted documents was approved by the Department of Community Safety in August 2011. Three autobiographies written by individuals who worked at Boggo Road Gaol provided historical detail about the operation of the prison from various personal perspectives. These included Boggo road prison: riots to ruins (Gage 2009); Boggo Road and beyond (King 2007); and Nor iron bars a cage (Stephenson 1982). The authors worked at the Boggo Road Gaol complex at various stages between 1936 and 1989.

The analytical process began with a preliminary qualitative content analysis of the graffiti to identify key themes represented. The current study drew on the analytical technique suggested by Altheide (1996) in relation to media photos. Each item of graffiti was reviewed, and its form - written or image, as well as a brief description of its content - was documented systematically. To allow reflective interpretation, our analysis extended beyond the manifest content of the images to include latent content - 'an interpretive reading of the symbolism underlying the physical data' (Berg 2009: 344) - and the process was predominantly, although not exclusively, inductive. The items of graffiti were reviewed many times. During subsequent reviews, patterns emerged and the graffiti was coded thematically. The identified themes were continuously assessed as other data sources were analysed.

Following the initial analysis of the graffiti, qualitative content analysis was undertaken in relation to the newspaper articles and official reports by adapting the techniques described by Altheide (1996) and Hwang (2008). The documents were uploaded into Atlas.ti version 6.2. Each of the articles and reports was coded paragraph by paragraph, identifying the themes devised from the graffiti analysis. Sections of the articles that did not correspond to the devised themes were coded accordingly. Notes and memos on each article and report were recorded to document information such as the content of accompanying pictures (if applicable), important subjects, incidents and related factors. The institutional records and autobiographies were also reviewed to identify information relating to the themes derived from the graffiti analysis. Overall, the analytical process was iterative, both within and between the respective data sources. All of the sources of data (and accompanying notes and memos) were viewed numerous times throughout the analysis to identify emerging patterns, and to ensure consistency.

\section{Findings: Contextualising Resistance in Boggo Road Prison Graffiti}

Three dominant themes were identified in the initial graffiti analysis: resistance, identity and coping. The respective themes were represented in the contextual data analysed in the study (newspaper articles, official reports, institutional records 
and autobiographies) to varying degrees. Resistance, identity and coping are not necessarily discrete themes - they are interrelated, and as a whole represented prisoners' resistance to experience of incarceration. While each theme warrants deeper theoretical consideration, this article focuses on the theme of resistance, to demonstrate how social, historical and political context can aid in the interpretation of images.

Resistance was frequently and clearly portrayed in the graffiti observed at Boggo Road Gaol through symbols and written accounts. Symbols included swastikas, anarchy signs, clenched fists (both with and without the middle finger extended), Indigenous flags and images of weapons. Written accounts consisted of both narratives and short statements, often including words such as 'liberty', 'triumph', 'freedom', 'justice' and 'dog'. Foucault (1978) argues that even within the prison environment, power is never certain nor complete. Although prison officials enhance their potential power through practices such as surveillance and the gathering of information, the exercise of power and control is dependent upon a complex network, and resistance is natural. The chief prison officer's journal (QSA Item ID 304103) describes a typical day at No. 2 Division in 1981:

6:30: division unlocked

6:40: meal muster

8:00: routine activities

11:30: meal muster

15:30: evening meal muster

16:30: evening lock up muster

21:30: television terminated

A 'Notice to all Prisoners' (see Figure 2) from the Prison rules and orders book, 1957-61 provides further insight into the restrictions placed on prisoners at Boggo Road Gaol. Much of the graffiti that reflects resistance falls into two broad categories: institutional resistance, and Aboriginal and Torres Strait Islanders' resistance. The examples of the graffiti below are discussed in relation to information provided from the analysis of the contextualising data deployed in the study.

\section{Institutional Resistance}

Institutional resistance consisted of graffiti aimed at the prison and its staff, or that contained expressions of anti-authority more generally. Figure 3 provides an example of graffiti reflecting resistance towards Boggo Road Gaol and its staff. The dominant feature of the graffiti is an image of a cellblock labelled ' $\mathrm{F}$ ', with two figures proclaiming 'justice now' drawn on the rooftop. Analysis of the contextual data highlighted the significance of this image (and others reflecting resistance), suggesting it is representative of the prison during the 1980s. The roof of F cellblock was the site of three protests mentioned in the Courier-Mail. In April 1988, two prisoners carried out a four-hour protest on the roof of $\mathrm{F}$ cellblock before being removed by prison officers ('Prison protest' 1988). One of the protesters had been involved in a previous rooftop protest in 1986, in which prison officers were injured as prisoners threw objects from the rooftop ('Inmate's 1986' 1988). A further 


\section{NOTICE TO ALL PRISONERS.}

1. Cells must be kept clean and tidy. Unnecessary property, including letters, must be destroyed, or, if required for genuine reasons, must be handed to the Storekeeper, to be placed with the prisoner's property. Permission to have personal property must be obtained from the Superintendent.

2. Three books only, including magazines or periodicals, are allowed in the cell at any one time. Regular changes of books are available.

3. The defacing of cells walls, including writing thereon, is a Breach of the Regulations and will be dealt with as such. Each prisoner is held responsible for the good order of his cell, including the cell walls and ceiling. Any defacements are to be reported to the Chief Warder immediately the cell is occupied.

4. Noises in cells, including shouting and talking, are forbidden. Bad language or insolence will not be tolerated and is a breach of Regulations.

5. Prisoners are expected to be clean, punctual and tidy on all parades. Talking in ranks or on parade is forbidden.

6. Requests for information or advice may be made to the Superintendent through the Chief Warder.

7. The Visiting Surgeon visits the Prison at least twice weekly. Requests for his advice may be made through the Chief Warder.

8. The Visiting Justice visits the Prison frequently. Prisoners may see him about any problems within his jurisdiction.

9. If your relatives or friends intend to send money or valuables, ask them to register the package.

10. Good conduct and industry at any work and at all times are essential to qualify for remissions under the Regulations. In accordance with a prisoner's previous criminal history, remissions of $1 / 4,1 / 5$, or $1 / 6$ of his full sentence may be granted provided he is of good conduct and industry. Failure to work diligently, even if conduct is good, may mean ineligibility for remission.

11. Reception letters are granted on admission, when required.

\section{REMEMBER:}

(a) Good conduct and industry will qualify you for the full remission due under the Regulations.

(b) DON'T be misled or misguided into breaking the Regulations, or you will find, as all others have done, that such conduct can only have an adverse effect on you and the whole Prison. Discipline is the purpose of the Prison.

(c) If in doubt, ask an official for advice.

(d) Courtesy and obedience are in your interest.

Figure 2 Notice to all Prisoners. Reproduced from the Prison rules and orders book, 1957-1961 (QSA Item ID 271617). 


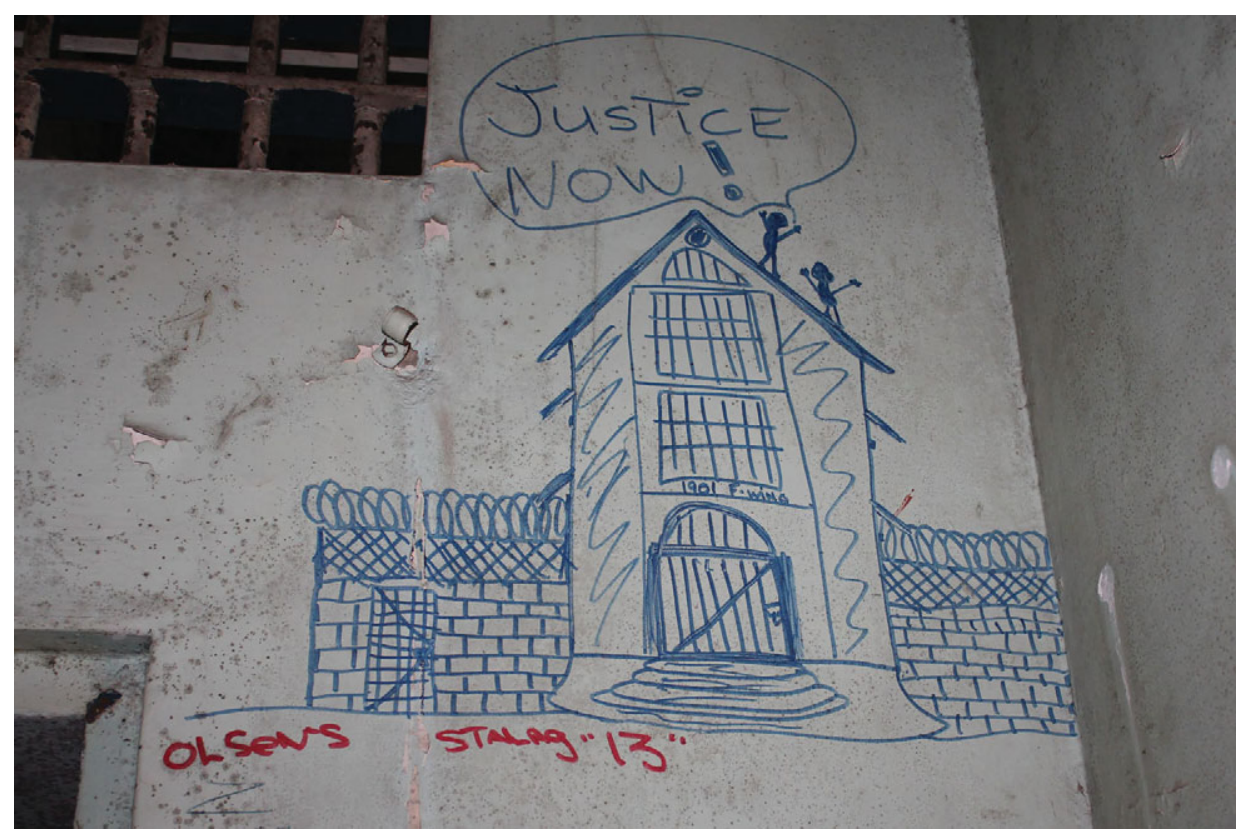

Figure 3 (Colour online) Rooftop protest and Olsen's Stalag. Source: Private collection.

protest was initiated by five prisoners on 25 February 1988 and ended on 2 March 1988 ('Prisoners go' 1988). The prisoners painted the slogan 'justice now — public inquiry' on the roof and other slogans on sheets: 'Stop all torture now', 'Don't let the hunger-strikers die - act now' and 'Close Division 2 now' ('Ignore five' 1988: 2). The Courier-Mail ('Ignore five' 1998: 2; 'Liberty council' 1998: 5) featured photographs of the protesters on the rooftop of cellblock F.

A hunger strike had been in progress for two weeks at Boggo Road Gaol at the time the February rooftop protest began ('Hunger strike' 1988). While only one prisoner initiated the hunger strike on 13 February ('Jail hunger-strike' 1988), up to 400 prisoners (including the rooftop protesters) eventually became involved ('Hunger strike' 1988). In his autobiography, Gage (2009: 144) notes: 'November 1983, saw us move into the hunger strike era and prisoner's opposition to 'Lawful Authority' was on the rise ...'

In 1988, consistent with media reports, the Kennedy Report (Kennedy 1988b) claimed the Boggo Road Complex was plagued with problems. In addition to protests and hunger strikes, other acts of resistance mentioned in the CourierMail included riots, escapes, attempted escapes and self-harm. The poor physical conditions of the gaol and assaults against prisoners frequently were referred to as underlying reasons for prisoner resistance. A number of items of graffiti we observed made reference to the conditions of the prison. '83-89 6 years in hell!', 'Two Jail The Five star Hotel for Anamil's that's all its fit for ...', and 'GENTLEMEN JOE 4-10-88 I'm listen to 4ZZZ About Prisoner bashing it happen here Last week' [sic.] all represent prisoners' resistance.

The graffiti shown in Figure 3 identifies the cellblock depicted as 'OLSEN'S STALAG “13"'. A consideration of historical, social and political context aids in interpreting the text. In his autobiography, Gage (2009) identifies Kelvin Olsen as 
a former prison officer. Stalag 13, officially known as 'Stammlager XIII C', was a prisoner of war camp during World War II (Hatton n.d.). The Australian population, however, is perhaps most familiar with Stalag 13 as it was portrayed in the comedy television series Hogan's Heroes. The program first featured on commercial television stations in Queensland in the early 1970s and was repeated during the mid-1980s (Television.au 2013). In the fictional program, the German captors are unknowingly ridiculed by their captives. The captives initiate a number of pranks against their captors, and plot numerous escapes. Unaware of the antics of the captives, the captors believed they are in control (Internet Movie Database 2013).

Another former staff member of the prison, Bill Irvine, a superintendent at Boggo Road Gaol during 1987 and 1988, was frequently cited in the graffiti. In his autobiography, Stephen Gage (2009: 69) describes Irvine as 'progressive and advanced in his thinking for the confinement of convicts and was most respected by all staff that had contact with him'. Based on the content of the graffiti observed - for example 'SACK IRVINE The DOG', and 'IRVINE IS THE BIGEST Dog AND KID FUCKER THAT HAS EVER BEEN A SUPER AT BOGG!' - it appears prisoners had a different view of Irvine. Cohen and Taylor (1972) note that, due to their incapacitation, prisoners were restricted in terms of to whom they could target their resistance, and therefore prison staff were likely recipients of prisoner resistance. A number of items of graffiti referred to prison staff in general such as 'Dog SCREWS' and 'LOOK AT ME NOW SCREW AND REMEMBER! REMEMBER WHEN I PLUCK OUT YOUR EYES AND CRUSH THEM IN MY FIST. GIVE YOU A SEEING EYE DOG TO SEE WITH! LOOK AT ME NOW DOG EYES! LOOK AT ME NOW!'

Graffiti reflecting institutional resistance extended beyond Boggo Road Gaol and its staff to more general sentiments of anti-authority. Anarchy symbols, swastikas and phrases such as 'fuck the system' and 'FTW' were frequently observed in the graffiti. Negative perceptions of the police and suspected corruption among public officials expressed in newspaper and official reports like the Fitzgerald Inquiry provide a context for the interpretation of graffiti expressing anti-authority sentiments. The report of the Fitzgerald Inquiry (Fitzgerald 1989) discussed allegations of widespread misconduct in the Queensland Police Force, as well as misconduct among political figures. It suggested that illicit activities such as the distribution of illegal drugs, prostitution and illegal gambling were facilitated by some corrupt public officials. A number of concerns in relation to the Queensland Police Force included inadequate training, education and resources, and a lack of independent evaluation and investigation into the activities of officers. Furthermore, the report noted negative community attitudes of the police: 'For its part, the community has unfavourable perceptions of police behaviour, attitudes, efficiency and competence.' (Fitzgerald 1989: 210)

Analysis of the Courier-Mail articles revealed that one former prisoner of Boggo Road Gaol, James Finch, had a particular interest in the Fitzgerald Inquiry. Finch and John Andrew Stuart were convicted of firebombing the Whiskey Au Go Go Nightclub, and both were sentenced to life imprisonment (Blanch 1988). Stuart died in custody in 1979 ('Cops knew' 1988). Finch was released on parole in 1988 and deported to England (Ross, Kennedy and Rowett 1988). A number of articles in the Courier-Mail suggested Finch and Stuart were subject to police verballing - 'the fabrication with or tampering with evidence' (Fitzgerald 1989: 363), and the pair's 


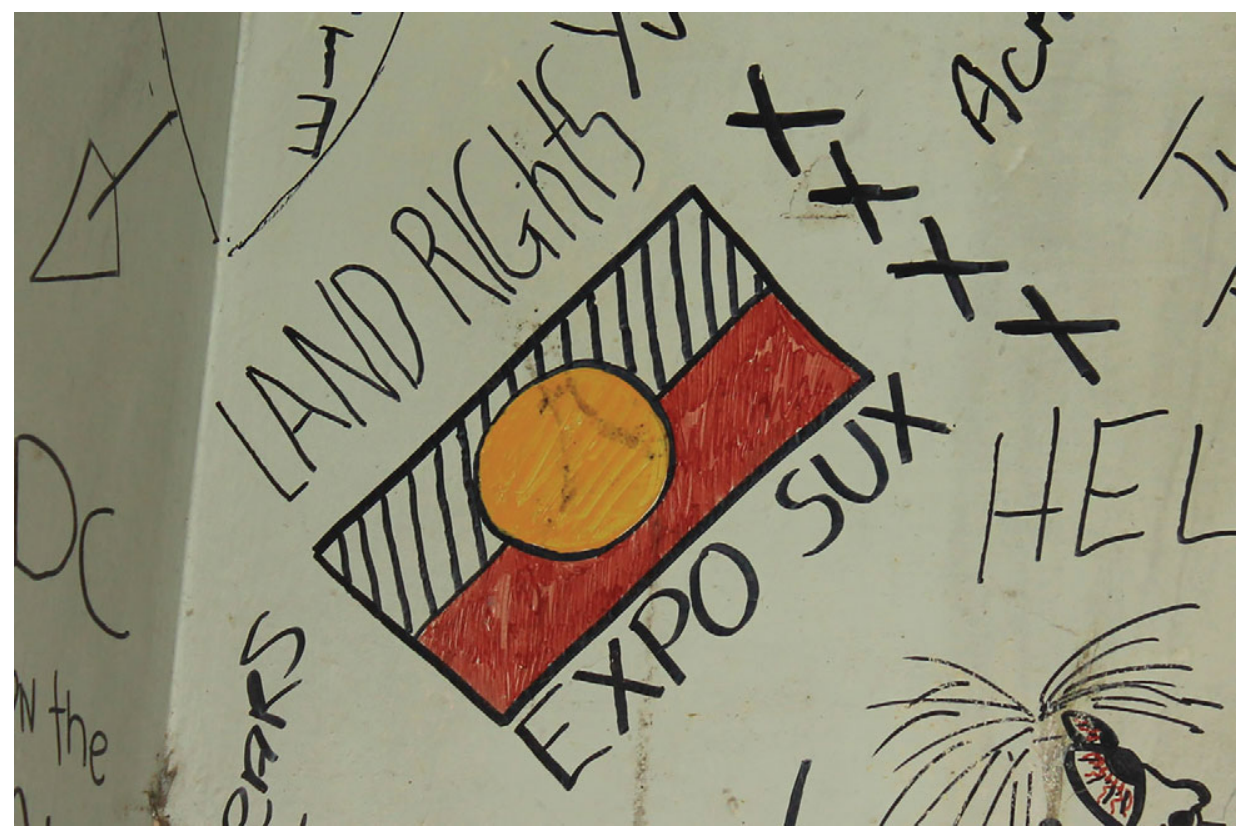

Figure 4 (Colour online) Land Rights, Expo Sux. Source: Private collection.

innocence with regard to the Whiskey Au Go Go case was variously supported or refuted. The Courier-Mail (Ross, Kennedy and Rowett 1988; Rowbotham 1988) documented Finch's desire to come back to Australia, following his deportation, to give evidence at the Fitzgerald Inquiry.

\section{Aboriginal and Torres Strait Islander resistance}

Aboriginal and Torres Strait Islanders' symbols and expressions of resistance were common features on the walls of Boggo Road Gaol. The item of graffiti in Figure 4 captures the significance of the graffiti throughout the prison, and the issues confronting Australia's First Peoples in Queensland during the 1980s. It contains an image of the Indigenous flag with the words 'LAND RIGHTS' written above. In 1982, Eddie Mabo and four other Indigenous Australians initiated legal action against the Queensland government, seeking recognition of the land rights of Aboriginal and Torres Strait Islander peoples (McRae et al. 2003). The High Court case spanned ten years, eventually resulting in the passage of the Native Title Act (1993). Graffiti proclaiming land rights and the words 'Eddie A.T.8.' was observed frequently throughout No. 2 Division.

The graffiti in Figure 4 also contains the words 'EXPO SUX'. World Expo '88, held in Brisbane, was part of the bicentennial celebration of European settlement in Australia. The event attracted local, national and international visitors (Foundation Expo '88 2010). The National Centre for Studies in Travel and Tourism (1989) estimated that 16,465,000 visits were made to the Expo during the six months in which it operated. Some of the Aboriginal and Torres Strait Islander graffiti appeared to relate specifically to the bicentenary - for example, 'Murries ARE from the begining NOT 200 years' [sic.], 'INVASION, YOUR UNREPENTED SIN' and the Indigenous representation of Australia shown in Figure 5. 


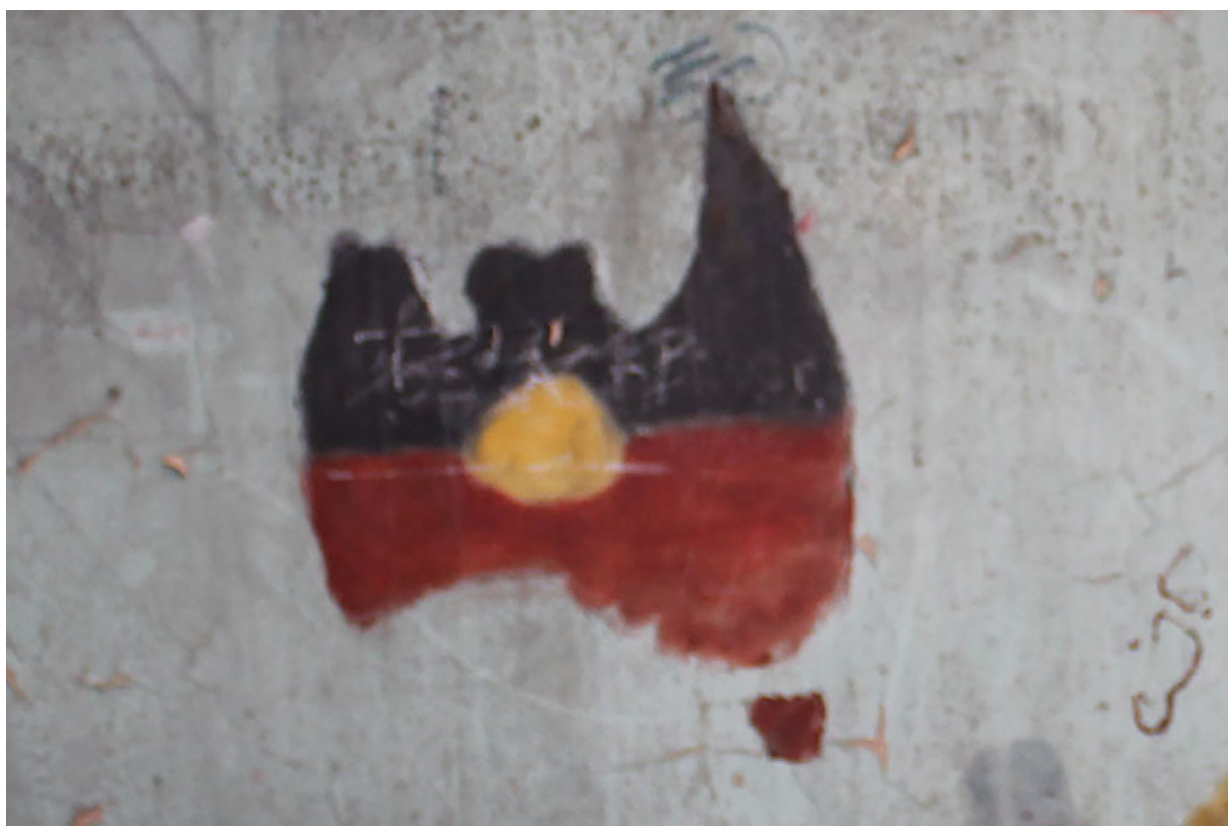

Figure 5 (Colour online) Indigenous representation of Australia. Source: Private collection.

Two years after the closure of No. 2 Division of Boggo Road Gaol, reporting on investigations carried out during the 1980s, the RCIADIC (Johnston 1991) discussed poor relations between Aboriginal and Torres Strait Islanders and nonIndigenous Australians. Johnston suggested that for many of Australia's First Peoples, their over-representation in custody, and over-representation in the number of deaths in custody, reflected past injustices faced during the periods of dispossession, colonisation and assimilation. In the Regional Report of Inquiry in Queensland for the RCIADIC, Wyvill (1990) notes resistance from the Queensland government regarding his investigations into underlying issues surrounding the deaths of Indigenous Australians in custody in that state. However, a change of government in 1989 (the year No. 2 Division closed) brought greater cooperation and assistance with the investigations (Wyvill 1990). Evidently, the historical, social and political context surrounding the creation of Indigenous graffiti provided a foundation that aided the interpretation of the images.

\section{Conclusions}

Much of our understanding of incarceration is shaped by official accounts derived from analysis of prison records, correctional statistics, prison census data and governmental inquiries. These largely focus on institutional and/or governmental needs and priorities, rather than the personal interests and experiences of incarcerated individuals (Adams 1992; King and Liebling 2008). Other criminological research has conducted surveys or structured interviews to obtain information on prisoners' perspectives of incarceration (for example, Schneider et al. 2011; Winfree, 
Newbold and Tubb 2002). While this research allows prisoners' voices to be heard to some extent, the data obtained are influenced by the aims of the research and the questions asked (Jones 1995). This study was interested in graffiti as the subject of research. We were interested in graffiti as a source of data providing insight into the lived experiences of prisoners. It is the graffiti itself - the independent expression of prisoners - that guides the research, rather than institutional or researcher needs.

This article investigates visual ethnography as a methodology for the analysis of graffiti. The examples of the graffiti observed at Boggo Road Gaol reflecting resistance were positioned in relation to information contained in the newspaper articles, official reports, institutional records and autobiographies analysed in the current study. This demonstrated how the respective sources of data provided a historical, social and political context for an interpretation of the images under study. Viewed in isolation, a meaningful interpretation of the graffiti at Boggo Road Gaol is limited. Contextual analysis strengthens interpretation of images through the process of triangulation. Repetitions of themes both within and across the various data sources are identified, and convergences of meaning emerge. The convergence of meaning contributes to the analysis in important ways, identifying the significance of the graffiti and potentially reducing ambiguity associated with the interpretation of images. Visual ethnographic methodology provides an effective framework for the contextual analysis of images. It allows the historical, social and political context surrounding the creation of the images to be taken into consideration, providing the images with 'a voice' and enhancing reflective evaluation. In turn, this provides a narrative of prison life in Queensland that appreciates important factors beyond the prison environment itself.

This contrasts with other ways in which graffiti has been used as a source of data. Studies focusing on the manifest content of graffiti can tell us what and how often symbols are used, and how the symbols and images differ according to the characteristics of the artist. However, they do not allow a rich understanding of the meaning of the graffiti. Similarly, event-related studies are situationally functional, and do not allow an interpretation of what the graffiti means on a broader level. Analysis is restricted to the trigger event itself. This study extended the prison graffiti research conducted by Klofas and Cutshall (1985) and Wilson (2008b, 2008c). While these researchers incorporated resources relevant to the prisons in their analyses, a broader appreciation of context is necessary. It is only by locating the graffiti in the broader historical, social and political context that we can begin to appreciate graffiti as a form of expression - an artefact that tells us about prison life.

The current study exemplifies the view of Sykes $(1958 / 2007)$ that prison is a 'society within a society'. Although prisons attempt to place a physical barrier between prisoners and the outside world, it is not possible to completely separate them from the wider society. This was evident in the graffiti presented above - for example, images referring to land rights and Expo, as well as popular culture. When analysed in the broader historical, social and political context, graffiti is a valuable source of data that can provide insight into the lives of incarcerated offenders. It highlights that fact that incarcerated offenders are not passive actors in the prison environment, and nor are they completely separated from the broader social issues on the outside. 


\section{References}

Abel, E. and Buckley, B. 1977. The handwriting on the wall: towards a sociology and psychology of graffiti. Westport, CT: Greenwood Press.

Adams, K. 1992. 'Adjusting to prison life', Crime and Justice 16: 275-359.

Alderman, D. and Ward, H. 2008. 'Writing on the plywood: toward an analysis of hurricane graffiti', Coastal Management 35: 1-18.

Altheide, D. 1996. Qualitative media analysis. Thousand Oaks, CA: Sage.

Berg, B. 2009. Qualitative research methods for the social sciences, 7th ed. Boston: Allyn \& Bacon.

Blanch, K. 1988. 'No bars to jail interview, says Minister'. Courier-Mail, 3 February: 4.

Boggo Road Gaol Historical Society 2011. Website, http://www.boggoroadgaol.com. au/default.html (viewed 15 June 2013).

Bull, M. 2010. Punishment and sentencing risk, rehabilitation and restitution. Melbourne: Oxford University Press.

Cohen, S. and Taylor, L. 1972. Psychological survival: the experience of long-term imprisonment. Harmondsworth: Penguin.

'Cops knew, says report'. 1988. Courier-Mail, 7 February: 5.

Dawson, C. 2005. A pit of shame. Boggo Road's executed prisoners and South Brisbane Cemetery. Brisbane: Boggo Road Gaol Historical Society.

Dawson, C. 2007. The illustrated Boggo Road dictionary of prison language, slang and flash. Brisbane: Boggo Road Gaol Historical Society.

Dawson, C. and Wood, F. 2005. Last prison standing: a short history of Boggo Road's No. 2 Division 1903-1989. Brisbane: Boggo Road Gaol Historical Society.

Findlay, M. 1982. The state of the prison: a critique of reform. Bathurst: Mitchellsearch Limited.

Fitzgerald, T. 1989. Report of Commission of Inquiry into Possible Illegal Activities and Associated Police Misconduct, http://www.cmc.qld.gov.au/research-andpublications/publications/police/the-fitzgerald-inquiry-report-1987201389 (viewed 15 June 2013).

Foucault, M. 1978. Discipline and punishment: the birth of the prison, trans. A. Sheridan. New York: Vintage Books.

Foundation Expo '88. 2010. 'About World Expo '88', http://www.foundationexpo88. org/aboutcontents.html (viewed 15 June 2013).

Gage, S. 2009. Boggo Road Prison: riots to ruin, 1976-2008. Melbourne: Sid Harta.

Hagan, C. A., et al. 1999. 'Graffiti on the Great Plains: a social reaction to the Red River Valley Flood of 1997', Applied Behavioural Science Review 7: 145-58.

Hanauer, D. 2004. 'Silence, voice and erasure: psychological embodiment in graffiti at the site of Prime Minister Rabin's assassination', The Arts in Psychotherapy 31: 29-35.

Hatton, G. n.d. 'American prisoners of war in Germany', http://www.b24.net/pow/ stalag13.htm (viewed 15 June 2013).

'Hunger strike in jail continues'. 1988. Courier-Mail, 28 February: 2.

Hwang, S. 2008. 'Utilising qualitative data analysis software. A review of Atlas.ti.', Social Science Computer Review 26: 519-27. 
'Ignore five protesters on jail roof - Minister'. 1988. Courier-Mail, 26 February: 2.

'Inmate's 1986 protest earns 6-month term'. 1988. Courier-Mail, 23 April: 23.

Internet Movie Database 2010. 'Plot summary for Hogan's Heroes', http://www.imdb. com/title/tt0058812/plotsummary (viewed 15 June 2013).

'Jail hunger-strike tally now 9'. 1988. Courier-Mail, 20 February: 16.

Johnson, L. 2009. 'Jail wall art and public criminology', Research and Practices in Social Sciences 5: 1-21.

Johnston, E. 1991. Report of Royal Commission into Aboriginal Deaths in Custody, http://www.austlii.edu.au/au/other/IndigLRes/rciadic (viewed 15 June 2013).

Jones, R. 1995. 'Uncovering the hidden social world: insider research in prison', Journal of Contemporary Criminal Justice 11: 111-19.

Kennedy, J. 1988a. Commission of Review into Corrective Services in Queensland 1988 - Interim Report, http://www.correctiveservices.qld.gov.au/Publications/ Corporate_Publications/Reviews_and_Reports/index.shtml (viewed 15 June 2013).

Kennedy, J. 1988b. Commission of Review into Corrective Services in Queensland 1988 - Full Report, http://www.correctiveservices.qld.gov.au/Publications/Corporate_ Publications/Reviews_and_Reports/index.shtml (viewed 15 June 2013).

King, T. 2007. Boggo Road and beyond. Canberra: National Library of Australia.

King, R. and Liebling, A. 2008. 'Doing research in prisons'. In R. D. King and E. Wincup (eds), Doing research on crime and justice, 2nd ed. New York: Oxford University Press, pp. 431-55.

Klingman, A. and Shalev, R. 2001. 'Graffiti: voices of Israeli youth following the assassination of the Prime Minister', Youth Society 32: 403-12.

Klofas, J. and Cutshall, C. 1985. 'Unobtrusive research methods in criminal justice: using graffiti in the reconstruction of institutional cultures', Journal of Research in Crime and Delinquency 22: 355-73.

'Liberty council wants reform now'. 1988. Courier-Mail, 1 March: 5.

McRae, H., et al. 2003. Indigenous legal issues: commentary and materials, 3rd ed. Sydney: Law Book Company.

National Centre for Studies in Travel and Tourism. 1989. 'Expo 88 impact. The impact of World Expo 88 on Queensland's tourism industry', http://www. foundationexpo88.org/impact.pdf (viewed 15 June 2013).

Native Title Act 1993 (Cth).

Olowu, A. 1983. 'Graffiti here and there', Psychological Reports 53: 986.

Otta, E., et al. 1996. 'Musa latrinalis: gender differences in restroom graffiti', Psychological Reports 78: 871-80.

Pink, S. 2007. Doing Visual Ethnography, 2nd ed. London: Sage.

Public Sector Management Commission. 1993. Review of the Queensland Corrective Services Commission, http://www.correctiveservices.qld.gov.au/Publications/ Corporate_Publications/Reviews_and_Reports/index.html (viewed 15 June 2013).

'Prison protest foiled'. 1988. Courier-Mail, 22 April: 3.

'Prisoners go back to cells after roof-top protest ends'. 1988. Courier-Mail, 3 March: 10.

Prison Rules and Orders Book - H.M. Prison Brisbane (Boggo Road)/Brisbane prison complex, 1957-61. Queensland State Archives (QSA), item ID 271617.

Superintendent's punishment book — Brisbane Correctional Centre, 1959-71. QSA, item ID 271619. 
Chief prison officer's journal, prison complex (Boggo Road), 1979-1983, item ID 304101, 304103, 304104, 304105.

Rodriguez, A. and Clair, R. 1999. 'Graffiti as communication: exploring the discursive tensions of anonymous text', Southern Communication Journal 65: 1-15.

Ross, D., Kennedy, N. and Rowett, L. 1988. 'Finch vows: I'll come back to tell the truth'. Courier-Mail, 17 February: 1.

Rowbotham, J. 1988. 'Finch gets hot reception'. Courier-Mail, 19 February: 10.

Schneider, K., et al. 2011. 'Psychological distress and experience of sexual and physical assault among Australian prisoners', Criminal Behaviour and Mental Health 21: 333-49.

Sechrest, L. and Flores, L. 1969. 'Homosexuality in the United States and the Philippines: the handwriting on the wall', Journal of Social Psychology 79: 3-12.

State of Queensland, Department of Community Safety. 2013. 'History of corrective services in Queensland', http://www.correctiveservices.qld.gov.au/about_us/history/ history.shtml (viewed 19 June 2013).

Stephenson, R. 1982. Nor iron bars a cage. Brisbane: Boolarong.

Stocker, T. L., et al. 1972. 'Social analysis of graffiti', Journal of American Folklore 85: 356-66.

Sykes, G. 2007 [1958]. The society of captives: a study of a maximum security prison. Princeton, NJ: Princeton University Press.

Television.au. 2013. 'The history of Australian television', http://televisionau.com (viewed 12 June 2013).

Victorian Office of Corrections. 1990. 'Predicting major prison incidents', http://www. criminologyresearchcouncil.gov.au/reports/12-87.pdf (viewed 15 June 2013).

Wales, E. and Brewer, B. 1976. 'Graffiti in the 1970s', Journal of Social Psychology 90: 115-23.

Willett, R. 1996. 'Drafting an anti-graffiti ordinance - some essential provisions', http://anti-graffiti.org/anti-graffiti-legislation/drafting-an-anti-graffiti-ordinance (viewed 15 June 2013).

Wilson, J. 2008a. Prison cultural memory and dark tourism. New York: Peter Lang.

Wilson, J. 2008b. 'Racist and political extremist graffiti in Australian prisons, 1970s to 1990s', Howard Journal 47: 52-66.

Wilson, J. 2008c. 'Transgressive decor: narrative glimpse in Australian prisons, 1970s1990s', Crime Media Culture 4: 331-34.

Wilson, J. 2008d. 'Pecking orders: power relationships and gender in Australian prison graffiti', Ethnography 9: 99-121.

Winfree, L. Jr, Newbold, G. and Tubb, S. III 2002. 'Prisoner perspectives on inmate culture in New Mexico and New Zealand: a descriptive case study', Prison Journal 82: 213-33.

Wyvill, L. 1990. Royal Commission into Aboriginal Deaths in Custody, Regional Report of Inquiry in Queensland, http://www.austlii.edu.au/au/other/IndigLRes/rciadic/ regional/qld (viewed 15 June 2013).

Yogan, L. and Johnson, L. 2006. 'Gender differences in jail art and graffiti', South Shore Journal 1: 33-52.

Zdenkowski, G. and Brown, D. 1982. The prison struggle changing Australia's penal system. Ringwood: Penguin. 